\title{
Gibbs, E. (2021). Coal Country: The Meaning and Memory of Deindustrialization in Postwar Scotland. University of London Press.
}

\section{Review by Tim Strangleman}

These are exciting times to be in the field of deindustrialisation studies. There is a real sense of momentum and dialogue between the various studies emerging from a range of projects across the globe. In addition, a new generation of scholars who work naturally across disciplinary boundaries has emerged. There is a strong affinity between those researching deindustrialisation and the interdisciplinary field of working-class studies. In many ways working-class studies really owes its existence to the profound shock of industrial closures of the 1970s and 1980s, a process which revealed class politics and cultures at the point of loss or serious erosion. These issues frame Ewan Gibbs' fine new volume Coal Country, drawn from his doctoral research. This is an ambitious book, seeking to tell the story of the Post-World War Two coal industry in Scotland and its long-term demise.

Organised around seven substantive chapters, Coal Country weaves together the experiences of three generations of miners and mining families, drawing on a rich seam of wonderful oral history narratives from thirty-five interviewees. Chapters in turn examine the industrial development of the Scottish coalfields, the moral economy of the industry, coal communities, gender, generations, coalfield politics, and deindustrialisation.

Scotland is one of the best-studied areas in the UK in terms of a collected, curated and cohesive set of oral history projects on industrial experience and working-class life. Through the members and associates of the Scottish Oral History Centre based in Glasgow, there has been a coherent longstanding attempt to tell the story of Scotland's industrial heyday and subsequent decline through a 'history from below' approach. This focussed coherence is in marked contrast to the scholarship of English industrial decline, which remains fragmented. Gibbs' book both draws on that established tradition, as well as makes a fine original contribution to it. This Scottishness is really central to the book, providing a geographic boundary which at once is large enough to say something meaningful, while simultaneously small enough to not lose sight of detailed coherence. Running through the volume are a number of themes, perhaps the most distinctive of which is the way industrial loss is wrapped around a growing sense of Scottish national identity, as distinct from a wider British one. Gibbs draws on Scottish historian Tom Devine's notion of deindustrialisation bringing about " a deep crisis of national identity" that stemmed from "a collective psyche" invested in heavy industry'(p. 242). Gibbs' Coal Country fleshes out this insightful comment by showing that industrial decline and closure were a feature of the Scottish coal industry from the late 1940s, pre-dating the Thatcher era by some margin. Closures and rationalisation unfolded in a peculiarly Scottish way that helped to shape nationalism and imprinted itself on the wider working-class experience.

The real value of Coal Country lies in the way Gibbs tell the story through generations of industrial workers, the oldest of whom experienced grinding poverty and injustice in the interwar period when the coal industry was under callous private ownership. There is more 
than one account here of families evicted from their coal company homes as the result of strike action, industrial downturn or blacklisting. Memories of these events were seared into individuals, families and communities, and helped shape post-war attitudes toward politics and industry. Gibbs shows how these embedded cultural norms and values explain why workers acted as they did from the 1950s through to the 1980s and beyond. He shows how there emerged a distinct moral economy within individual industrial districts and at the level of the Scottish area of the National Coal Board (NCB) as a whole. This moral order included a recognition of the importance of health and safety measures, the acceptance of closure of pits on the grounds of exhaustion of seams, and the value of trade unionism. As Gibbs and others have pointed out, this moral economy was not the monopoly of the working class, but was a feature shared by employers and politicians - part of a wider post-war political consensus, again with a clear Scottish character.

Scotland is also a useful space to show the complexity of working-class life, with relevance beyond the coal industry. Gibbs skilfully holds in tension multiple identities working-class people held: geographic (national, regional, local); religious (Catholic and Protestant); gendered; generational; and political (Labour, Communist and Scottish nationalist). These were identities that sometimes united, but more often divided, working-class life, and bring a unique flavour to the wider experience of deindustrialisation in Scotland.

Coal Country really comes alive when we hear the voices of workers from the oral history material; this is largely absent in the early background history in chapter 1 , which is a shame. I was torn here between needing to know and worrying what a more general reader might think of the account, which is fairly dense. The frustration I felt with that section increased when the oral history accounts began to be fed into the narrative. Indeed, I felt that Gibbs rather underused his material. The narratives he recorded were so rich we deserve to hear far more of them. This is always a tension in oral history in balancing the critical narrative arc the author intends with the need to let people 'speak for themselves'. The narratives in Coal Country are often so fascinating that they could be the basis of a short story. There is a real value in letting workingclass people speak, especially from an older generation. This lies in the reader becoming familiar with the timbre and cadence of speech patterns, the sense making of working-class life - in short, the articulacy of working people when given the opportunity to talk and, perhaps more importantly, be listened to.

One of the signature weaknesses of both working-class studies and deindustrialisation studies is their tendency to be backward looking; by which I mean their focus is how the past shaped the recent past. The frustration is often at how little we know of the impact of historical legacy on the much younger generations. How do younger working-class people make sense and meaning of industries that have little physical or economic presence in their lives? Coal Country shares this weakness. This absence is understandable, as researchers need to record rich reflections on the past by the generations that experienced both heydays and declines, but we also need to make space for the voices of the future.

Coal Country is a fine and valuable contribution to both working-class studies and the study of deindustrialisation. This is a well-written and insightful account of one industry's role in the unfolding of a national story. It is in its account of the role of industrial decline on progressive politics in Scotland that we see the potential for hope in a working-class future. Working-class people took employment in the coal industry because it provided income - sometimes good, often not so good. That industry was dangerous, polluting, injurious to health and environmentally a disaster. But once that industry has gone, people deserve a better range of 
possibilities for themselves and their children. Coal Country hints that such brutal industrial erasure has opened up a series of progressive futures.

\section{Reviewer Bio}

Tim Strangleman is Professor of Sociology at University of Kent, Canterbury, UK. He has written widely on work and deindustrialisation. His book Voices of Guinness: an Oral History of the Park Royal Brewery, was published by Oxford University Press in 2019, and he has recently co-edited The Routledge International Handbook of Working-Class Studies with Christie Launius and Michele Fazio. 